\title{
Molecular Docking of Citronellol, Geraniol and Ester Derivatives as Pim 1 Kinase Inhibitor of Leukemia Cancer
}

\author{
Galuh Widiyarti $^{1 *}$, Firdayani $^{2}$, Muhammad Hanafi ${ }^{1}$, Soleh Kosela ${ }^{3}$, Emil Budianto ${ }^{3}$ \\ ${ }^{1}$ Recearch Center for Chemistry (RCC-Chem), Indonesian Institute of Sciences (LIPI), PUSPIPTEK Serpong, \\ Tangerang Selatan, Banten, Indonesia15314 \\ ${ }^{2}$ Center of Pharmaceutical and Medical Tecnologies, Laptiab Building, PUSPIPTEK Serpong, Tangerang \\ Selatan, Banten, Indonesia 15314 \\ ${ }^{3}$ Department of Chemistry, Universitas Indonesia, Depok, West Java, Indonesia 16424 \\ *Corresponding author: galu001@lipi.go.id, galuh.laksmono @gmail.com
}

Received: February 2018; Revision: August 2019; Accepted: October 2019; Available online: November 2019

\begin{abstract}
The proviral insertion site in Moloney murine leukemia virus-1 (Pim1) kinase is overexpressed in many human cancer diseases. Inhibition of Pim1 kinase has been reported can suppress cell proliferation and induce apoptotic cell death, so that the protein could be chosen as drug target for the treatment of cancer. Citronellol and geraniol mainly contained in citronella oil that's one of Indonesian natural products have bioactivity as antitumor agents, so that both of the compounds can be used as guiding compound to be developed as chemoprevention and chemotherapeutic agent compounds for cancer especially for leukemia cancer. In this research, sixteen citronellol and geraniol esters as an inhibitor of leukemia cancer designed were docked based on their interaction with leukemia receptor target of Pim1 kinase by using Molegro Virtual Docker (MVD). The result showed that the binding citronellol and geraniol esters to Pim1 kinase are more stable and better affinity than the binding between citronellol and geraniol, indicated by rerank score were lower than rerank score of citronellol/geraniolPim1 kinase. The docking resulted in the four top-ranked compounds, namely, citronellyl caproate, citronellyl caprylate, geranyl caproate and geranyl caprylate with rerank score value from -182.560 to $-189.822 \mathrm{KJ} / \mathrm{mol}$. These compounds have hydrogen bonding with amino acid residues of Lys 67 and Asp 186 of an active site of Pim1 kinase. Based on Lipinski's rule of five, among of the four top-ranked compounds, citronellyl caproate and geranyl caproate were predicted have potency as new chemopreventive and chemotherapeutic agents for leukemia anticancer candidates.
\end{abstract}

Keywords: Citronellol, geraniol, ester, leukemia anticancer, Pim1kinase.

DOI: $10.15408 / j k v \cdot v 5 i 2.7195$

\section{INTRODUCTION}

Leukemia is the most prevalent cancer for children in the developed and the developing countries (Bernard and Christopher, 2014). The cancer treatment by surgery, radiation, chemotherapy and cancer drug usage has not shown satisfactory result yet so that the research and development of the drug for the cancer treatment is still very needed. The development of modern computational chemistry and computational biology plays a vital role in drug discovery process for diseases causing proteins such as cancer (Ravi et al., 2012; Arsianti et al., 2014). Today, the modern computational chemistry by molecular docking methods are widely used in the early stages of drug discovery, purposing to rank potential inhibitors as an alternative to the experiments in the laboratory. Molecular docking method can be used to simulate how the interaction of the compounds with a target proteins, predict chemical characters needed for drug activity and propose of drug candidate compounds that are potential to be synthesized and developed (Yanuar, 2012; Siswandono, 2015; Li et al., 2011).

The discovery and development of cancer drug either natural or synthetic drug from a natural product are expected to result in the drug with higher activity, lower toxicity, and more selectively. During the last few 
decades, chemopreventive and chemotherapeutic compounds against various types of cancer have been isolated from some number of medicinal plants (Christodoulu et al., 2013, Mandal et al., 2012; Qurishi et al., 2011; Cragg and Newman, 2013). Indonesian biodiversity has potential as a source of bioactive compounds as a chemopreventive and chemotherapeutic agent for cancer treatment. Citronella is an essential oil mainly found in Lemongrass plant, including in genus of Cymbapogon and family of Poaceae (Ganjewala, 2009). Indonesia is the third citronella oil producer in the world, after China and Vietnam. The major compounds in citronella oil are monoterpene compounds such as citronellol and geraniol reported have many bioactivities that is as antimicrobial, antibacterial, antifungal, antiviral, antiparasitic, antioxidant and anti-inflammatory (Bayala et al., 2014; Madnooni et al., 2012; Cavar et al., 2012; Sharma et al., 2009). Citronellol and geraniol also reported effective against malignant cell proliferation (Biblap and Jhinuk, 2013; Khan et al., 2013; Chen and Viljoen, 2010; Can and Buchbauer, 2010). The monoterpene compound is a novel class compound of cancer chemopreventive.

Citronellol and geraniol mainly contained in citronella oil are multipotent, which have many bioactivities through different mechanisms and different types of receptors so that citronellol and geraniol could be become guiding compound to be developed as chemoprevention and chemotherapeutic agent compounds for cancer especially for leukemia cancer. Citronellol and geraniol have been reported have cytotoxic activity against human cancer leukemia (HL60) cells with the $\mathrm{IC}_{50}$ value of 50 and $30 \mu \mathrm{g} / \mathrm{mL}$, respectively (Raut and Karuppayil, 2014; Kumar et al., 2008). The short and medium chain fatty acids were also reported have bioactivity as antimicrobial, antifungal, antiviral and potentially as antitumor agents (Narayanan $e t$ al., 2015; Fauser, 2014). Therefore the ester compounds derivative of citronellol and geraniol with fatty acids might be potential as leukemia anticancer.

The inhibition of protein kinases by selective inhibitors has become a dominant therapeutic approach for many diseases especially well established for cancer and a standard of modern clinical oncology (Grassow et al., 2014; Garcia et al., 2014). The proviral insertion site in Moloney murine leukemia virus-1 (Pim1) kinase belongs to a novel class of serine/threonine kinases with biochemical features regulating various oncogenic pathways, such as cell cycle progression and apoptosis resistance. Pim1 kinase is overexpressed in many human cancer diseases and has been associated with metastasis and overall treatment response. The experimental model study reported that inhibition of Pim1 kinase suppressed proliferation and migration cell, induced apoptotic cell death, and synergized with other chemotherapeutic agents so that Pim1 kinase is the preferential target for inhibition of the mitotic processing and can be chosen as drug target for the treatment of cancer (Gisele et al., 2016; Tursynbay et al., 2016; Matthew et al., 2015; Weirauch et al., 2013). Some compounds were reported to inhibit the activity of serine/threonine kinases of Pim1, such as imidazopyridazine, benzoimidazol, acylhydrazone, triazolopyridine, thiazolidine2,4-dione, pyridone, staurosporin, and bisindolylmaleimide (Merkel et al., 2012). Generally, the inhibitor of Pim1 are aromatic compounds. In this research, the study of acyclic compounds, citronellol and geraniol esters as inhibitors of Pim1 would be carried out. Therefore, citronellol, geraniol and ester derivatives of both of the compounds designed and chosen as an inhibitor of Pim1 kinase for treatment of leukemia cancer by using molecular docking method.

The purpose of the study is to find out Pim1 kinase inhibitor potential from citronellol and geraniol esters through analysis of binding free energy and hydrogen bonding interaction into Pim1. We conducted docking simulation to citronellol and geraniol esters as ligands into Pim1 as target receptor using Molegro Virtual Docker (MVD). There are more than 60 molecular docking software. Generally, the programs search the compounds with adequate and conformational space produce correct binding poses, but the score function is still need repairs. Thus, in general the assessment is truly objectively difficult to realize in comparing programs with one another, because of favoritism, the selection of test data is biased and the level difference proficiency in using different programs. Some of which have been used are: DOCK, FlexX, Glide, Gold, Autodock and Molegro Virtual Docker/MVD (Yanuar, 2012). Currently MVD 
is widely used for docking simulation studies, because besides being cheap and easy to use, MVD has an accuracy of up to $87 \%$, while Glide $82 \%$, Surflex $75 \%$ and FlexX $58 \%$ (Nogrady and Weaver, 2005 in Siswandono, 2015.

\section{MATERIALS AND METHODS}

In this study, we designed citronellol and geraniol esters and docked these compounds as based on their interactions with Pim1-kinase by using MVD 6.0 under licence of 2013.6.0.0-2013-05-21 computer software application to determine the best compound as inhibitor leukemia cancer. Analysis and screening were based on molecular docking (rerank) score, affinity, and hydrogen interaction of binding between compounds and the target protein.

Target protein was selected and downloaded from Protein Data Bank (PDB). The three- dimensional (3D) structure of the target protein of Pim1 kinase was also downloaded from PDB. The water and it's cofactor of protein molecule from Pim1 are eliminated. Furthermore, the active ligand contained in the protein is extracted, and then the active ligand is imported back into protein with the optimation of the position of $\mathrm{x}, \mathrm{y}, \mathrm{z}$ and radius in the protein. Furthermore, it is docked and see the value of Root Mean Square Deviation (RMSD). The method is valid if the value of RMSD $\leq 2$ (Gisele et al., 2016). The energy minimization of protein molecule was carried out using Amber v9 tools molecular dinamic (MD) software.

The structure of citronellol, geraniol, and ester derivative of these compounds as ligands were prepared and designed using ChemBioDrawUltra 12.0 software, and then copied into chembiodraw ultra 3D software and minimized of the energy of the compounds. The result is stored with the file format mol2. The next stage is docking of the ligand of compounds designed into protein Pim1 which the ligand exist on the protein already replaced. The value must be the same like in the validation method. The docking process was repeated for 20 times. Docking simulations, hydrogen interaction, binding of ligand and target protein were performed and visualized using software MVD. (Kusumaningrum et al., 2014)

\section{RESULTS AND DISCUSSION}

According to the USA's National Cancer Institute (NCI), murine leukemia (P388) cells is a tumour cells type that used a cytotoxic test protocol, which the test result using the cells is often used as base on test similar further in order to obtain a compound as candidate anticancer drug (Dykes et al., 2008). Therefore in the previous study the in vitro cytotoxic activity test of citronellol and geraniol as starting compounds were carried out against murine leukemia (P388) cells using MTT method. The result showed that citronellol and geraniol have potential as inhibitor of leukemia cancer, indicated by these compounds active against P388 cells with $\mathrm{IC}_{50}$ values of 38.49 and $28.12 \mu \mathrm{g} / \mathrm{mL}$ (Widiyarti et al., 2016). Ester compounds derivative of citronellol and geraniol expected to have cytotoxic activity higher than citronellol and geraniol due to the hydrophobicity of these compounds.

The eighteen compounds, including citronellol and geraniol, 16 of citronellol and geraniol esters designed using ChemBioDraw Ultra 12.0 software were prepared. The structure of citronellol and geraniol esters have been drawn on ChemBioDraw Ultra 12.0 software and imported to the MVD workspace in 'sdf' format. In order to make accurate predictions, it is important that the imported structures have been properly prepared, that is, the atom connectivity and bond orders are correct and partial atomiccharges are assigned (Kusumaningrum et al., 2014). After that, the ester compounds designed were then docked on target protein of Pim1 kinase as the receptor target using MVD. The crystal structure of Pim1 kinase downloaded directly from PDB that is accessed through the URL: http://www.rcbs.org/pdb. Criteria for selection of a protein as target receptor include this protein has an acceptable resolution $(<2.8 \AA)$, derived from Homo sapiens, and complex with small molecule ligand.

Pim1 kinase is part of the serinethreonine protein kinases that play a role in apoptosis, metabolism, cycles, and migration of cells in tumor growth. Pim1 kinase is also overexpressed in several types of human cancers and it's activity also reported as a promoter of carcinogenesis, so that it is postulated as a potential target of cancer therapy (Tursynbay et al., 2016; Matthew et al., 2015; Weirauch et al., 2013). Pim1 
downloaded from PDB with ID code of $5 \mathrm{wdr}$ selected due to has a resolution of $2 \AA$, descended from Homo sapiens and complexes with a small molecule ligand of [N-4(1R,3S,5S)-3-amino-5-methylcyclohexylpyridine-3-yl-6-(2,6-difluorophenyl)-5fluoropicolinamide (5H7_401(A)]. To determine the binding site area, MVD using encryption cavity detection will automatically search for the best position and identify as a potential binding site that called as cavities or active sites.

The structure of citronellol and geraniol esters that designed using ChemDraw Ultra 12.0 copied into ChemBioDraw Ultra 3D software, and minimized the energy of the compounds. The result was stored as mol 2 file formats, and import into MVD workspace in sdf formats. Furthermore the compounds positioned as the ligands docked as an inhibitor of the receptor of Pim1 kinase to see the potential leukemia anticancer activity of the compounds.

MVD has identified five different cavities in Pim1 kinase crystal structure and docking will be done in the cavity 1 of Pim1 kinase as shown in Figure 1. The validation of docking methods with 20 repetitions was done to ensure the orientation and position of binding of the ligand of 5H7_401 (A) that bounded to the Pim1 kinase protein (Gisele et $a l ., 2016)$. The location of ligand of 5H7_401 (A) is in the cavity 1 with volume of 155.136 ; surface of 437.76 with a radius of $13 ; \mathrm{X}=$ $41.56 ; \mathrm{Y}=-2.57 ;$ and $\mathrm{Z}=2.48$. The validation test showed that RMSD value of 0.396 , so that this method can be said to be valid.

Furthermore 18 compounds include citronellol, geraniol, 16 citronellol and geraniol ester compounds, and Artonin E as a standard anticancer be functioning as inhibitor ligands of Pim1 kinase, then docked to Pim1 kinase, which each ligand is determined the best position that indicated by docking (rerank) score. The value of rerank score of the docking results were assumed as free energy of the binding between the target receptor of protein and the inhibitor ligand. The negative value is greater indicates that the binding of ligandprotein is more stable, which means that the interaction between protein and ligand could inhibit the performance of the receptor of protein Pim1 kinase.(Gisele et al., 2016). The rerank score of the best position of each the binding of ligand-protein are shown at Table 1 and Table 2.

Citronellol and geraniol esters possible have cytotoxic activity better and more selective than citronellol and geraniol are possible due the increasing hydrophobicity properties and binding energy affinity towards protein as a binding target. The transformation of citronellol and geraniol structural into citronellol and geraniol esters by extending the carbon atoms chain to improve the hydrophobicity properties in order to enhance the selectivity of cytotoxic activity of the compounds. The hydrophobic character of the compound is one important character for the drug to be able to pass through cell membranes and interact with the receptor. Changes substituents on the structure of the drug have a significant effect on the hydrophobic character and biological activity. In general, the increasing of the hydrophobicity of the compound would increase biological activity, cause the drug compound must pass through the hydrophobic barrier of a cell membrane to reach the target (Siswandono, 2015). In the in vitro test, although no barrier must be passed, the drug compound must interact with the target system such as proteins or enzymes as receptors which normally hydrophobic binding site active. Besides, the transformation of structure of citronellol and geraniol by extending the carbon atom chain into ester compounds to aim for increasing of steric interaction to improve the biological activity. Nevertheles, according to the Lipinski's rule of five, generally the drug compound is as orally active drug if the hydrophobicity value is less than $5(\log \mathrm{P} \leq 5)$ (Lipinski, et al., 1997, Hannahan and Weinberg, 2010; Siswandono, 2015).

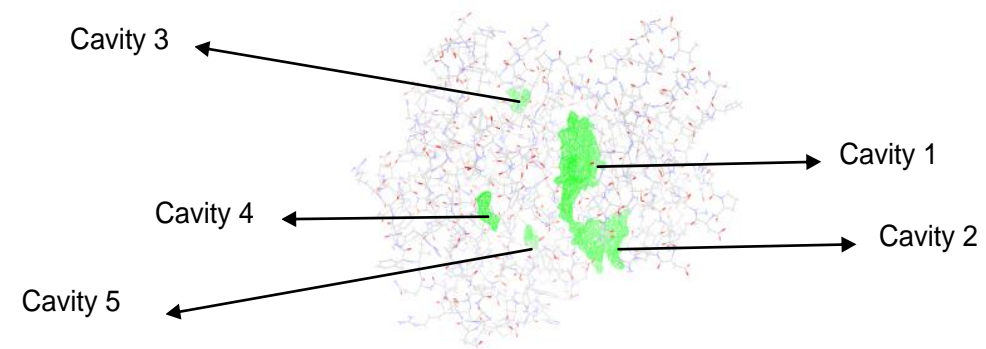

Figure 1. The cavity (active site) of Pim1 kinase (Matthew, et al., 2015) 
Table 1. The molecular docking result of citronellol esters as inhibitor of Pim1 kinase

\begin{tabular}{|c|c|c|c|c|c|}
\hline $\begin{array}{l}\text { Compound } \\
\text { Name }\end{array}$ & Molecular Structure & $\begin{array}{c}\text { Molecular } \\
\text { Formula }\end{array}$ & $\begin{array}{c}\log \\
\mathbf{P}\end{array}$ & $\begin{array}{c}\text { Rerank } \\
\text { Score } \\
(\mathbf{K J} / \mathbf{m o l})\end{array}$ & $\underset{\text { Interaction }}{\Sigma \mathbf{H}}$ \\
\hline Citronellol & & $\mathrm{C}_{10} \mathrm{H}_{20} \mathrm{O}$ & 2.82 & -130.133 & 2 \\
\hline $\begin{array}{l}\text { Citronellyl } \\
\text { valerate }\end{array}$ & & $\mathrm{C}_{15} \mathrm{H}_{28} \mathrm{O}_{2}$ & 4.54 & -169.086 & 2 \\
\hline $\begin{array}{l}\text { Citronellyl } \\
\text { isovalerate }\end{array}$ & & $\mathrm{C}_{15} \mathrm{H}_{28} \mathrm{O}_{2}$ & 4.45 & -170.504 & 1 \\
\hline $\begin{array}{l}\text { Citronellyl } \\
\text { propionate }\end{array}$ & & $\mathrm{C}_{13} \mathrm{H}_{24} \mathrm{O}_{2}$ & 3.71 & -162.294 & - \\
\hline $\begin{array}{l}\text { Citronellyl } \\
\text { butyrate }\end{array}$ & & $\mathrm{C}_{14} \mathrm{H}_{26} \mathrm{O}_{2}$ & 3.79 & -156.587 & 2 \\
\hline $\begin{array}{l}\text { Citronellyl } \\
\text { isobutyrate }\end{array}$ & & $\mathrm{C}_{14} \mathrm{H}_{26} \mathrm{O}_{2}$ & 4.26 & -170.767 & 1 \\
\hline $\begin{array}{l}\text { Citronellyl } \\
2,2 \text { dimetyl } \\
\text { butyrate }\end{array}$ & & $\mathrm{C}_{16} \mathrm{H}_{30} \mathrm{O}_{2}$ & 5.4 & -179.138 & 2 \\
\hline $\begin{array}{l}\text { Citronellyl } \\
\text { caproate }\end{array}$ & & $\mathrm{C}_{16} \mathrm{H}_{30} \mathrm{O}_{2}$ & 4.96 & -186.183 & 1 \\
\hline $\begin{array}{l}\text { Citronellyl } \\
\text { caprylate }\end{array}$ & & $\mathrm{C}_{18} \mathrm{H}_{34} \mathrm{O}_{2}$ & 5.79 & -184.669 & 1 \\
\hline $\begin{array}{l}5 \mathrm{H} 7 \_401[\mathrm{~A}] \\
\text { as reference } \\
\text { ligand }\end{array}$ & & $\begin{array}{c}\mathrm{C}_{24} \mathrm{H}_{17} \mathrm{~F}_{7} \mathrm{~N} \\
4 \mathrm{O}\end{array}$ & 2.39 & -132.299 & 3 \\
\hline & & $\mathrm{C}_{25} \mathrm{H}_{24} \mathrm{O}_{7}$ & 3.6 & -230.894 & 2 \\
\hline
\end{tabular}


Table 2. The Molecular Docking Result of Geraniol Esters as Inhibitor of Pim1 kinase

\begin{tabular}{|c|c|c|c|c|c|}
\hline $\begin{array}{l}\text { Compound } \\
\text { Name }\end{array}$ & $\begin{array}{l}\text { Molecular } \\
\text { Structure }\end{array}$ & $\begin{array}{l}\text { Molecular } \\
\text { Formula }\end{array}$ & $\begin{array}{c}\mathbf{L o g} \\
\mathbf{P}\end{array}$ & $\begin{array}{c}\text { Rerank } \\
\text { Score } \\
(\mathrm{KJ} / \mathbf{m o l}) \\
\end{array}$ & $\underset{\text { Interaction }}{\Sigma H}$ \\
\hline Geraniol & & $\mathrm{C}_{10} \mathrm{H}_{18} \mathrm{O}$ & 2.49 & -132.492 & 2 \\
\hline $\begin{array}{l}\text { Geranyl } \\
\text { propionate }\end{array}$ & & $\mathrm{C}_{13} \mathrm{H}_{22} \mathrm{O}_{2}$ & 3.37 & -160.623 & 1 \\
\hline $\begin{array}{l}\text { Geranyl } \\
\text { butyrate }\end{array}$ & & $\mathrm{C}_{14} \mathrm{H}_{24} \mathrm{O}_{2}$ & 3.79 & -172.164 & 1 \\
\hline $\begin{array}{l}\text { Geranyl } \\
\text { isobutyrate }\end{array}$ & & $\mathrm{C}_{14} \mathrm{H}_{24} \mathrm{O}_{2}$ & 3.94 & -178.661 & 1 \\
\hline $\begin{array}{l}\text { Geranyl } \\
\text { 2,2-dimetyl } \\
\text { butyrate }\end{array}$ & & $\mathrm{C}_{16} \mathrm{H}_{28} \mathrm{O}_{2}$ & 5.06 & -170.959 & 2 \\
\hline $\begin{array}{l}\text { Geranyl } \\
\text { valerate }\end{array}$ & & $\mathrm{C}_{15} \mathrm{H}_{26} \mathrm{O}_{2}$ & 4.21 & -171.619 & 2 \\
\hline $\begin{array}{l}\text { Geranyl } \\
\text { isovalerate }\end{array}$ & & $\mathrm{C}_{15} \mathrm{H}_{26} \mathrm{O}_{2}$ & 4.12 & -130.188 & 1 \\
\hline $\begin{array}{l}\text { Geranyl } \\
\text { caproate }\end{array}$ & & $\mathrm{C}_{16} \mathrm{H}_{28} \mathrm{O}_{2}$ & 4.62 & -183.598 & 2 \\
\hline $\begin{array}{l}\text { Geranyl } \\
\text { caprylate }\end{array}$ & & $\mathrm{C}_{18} \mathrm{H}_{32} \mathrm{O}_{2}$ & 5.46 & -189.822 & 1 \\
\hline $\begin{array}{l}5 \mathrm{H} 7 \_401[\mathrm{~A} \\
\text { ] reference } \\
\text { ligand }\end{array}$ & & $\begin{array}{c}\mathrm{C}_{24} \mathrm{H}_{17} \mathrm{~F}_{7} \mathrm{~N}_{4} \\
\mathrm{O}\end{array}$ & 2.39 & -132.299 & 3 \\
\hline Artonin E & & $\mathrm{C}_{25} \mathrm{H}_{24} \mathrm{O}_{7}$ & 3.60 & -230.894 & 2 \\
\hline
\end{tabular}

The docking simulation results showed that the rerank score of citronellol/geraniol esters lower than rerank score of citronellol and geraniol. The rerank score is the minimum free energy of the bond between a ligand with Pim 1 kinase as a target receptor. The minimum energy of binding between citronellol/geraniol esters as a ligand to Pim1 kinase as target receptor were lower than minimum energy of binding between citronellol/geraniol-Pim1 kinase. It indicated that the binding citronellol and geraniol esters 
to Pim1 kinase were stronger or more stable compared to binding between citronellol and geraniol to Pim1 kinase which allows inhibiting the performance of Pim 1 kinase in causing cancer, so that it will produce a higher anticancer activity of citronellol/geraniol esters than citronellol and geraniol.

Based on the minimum energy obtained from the docking simulation results, the ester compounds have a minimum energy lower than reference ligand and have hydrogen interaction with the amino acids of an active site of protein Pim1 kinase as a target receptor. It means ester compounds have potency as inhibitor of leukemia cancer cause the compounds can inhibit the performance of Pim 1 kinase. Generally, the minimum energy of esters are lower than minimum energy of citronellol/geraniol as starting material and a reference ligand of 5H7_401 (A), but higher than Artonin $\mathrm{E}$ that is a standard chemical compound commonly used in the cytotoxic test against murine leukemia (P388) cells. The minimum energy of citronellol, geraniol, reference ligand and Artonin E were $130.133,-132.492,-132.239$ and $-241.419 \mathrm{KJ} /$ mol, respectively.

The docking resulted in the four topranked compounds, namely, citronellyl caproate (CC), citronellyl caprylate (CK), geranyl caproate (GC) and geranyl caprylate (GK). The rerank scores of binding of these compounds to Pim1 kinase were -183.56 to $189.82 \mathrm{KJ} / \mathrm{mol}$. The docking results also showed these compounds have hydrogen interaction and steric interaction with amino acid residues of active site on Pim1 kinase. These compounds have hydrogen interaction with Lys 67 and Asp 186 on active site of Pim1 kinase, while the steric interaction with

Val 52, Leu 120, Asn 172, Asp 186 (CC); Asn 172, Ile 104, Leu 174, Val 126, (GC); Phe 49, Ile 104, Val 52 (CK); and Lys 67, Asp 186, Phe 187 (GK). The reference ligand have hydrogen interaction with amino acid residues of Lys 67 and Asp 128 on active site of Pim1 kinase, and steric interaction with Leu 44, Arg 122, Leu 174, and Glu 121, whilts citronellol and geraniol have hydrogen interaction with amino acid residues of Glu 89 and Phe 187 on the catalytic site of Pim1 kinase.

The interaction of the ligand with Pim 1 kinases is hydrogen bond between ligand such as alkyl group of ester compound or hydroxyl groups of alcohol as a ligand with amino acids of Pim 1 kinase. The more hydrogen bond of ligand-Pim 1 kinase indicated by the increasing number of hydrogen interaction of ligand-Pim 1 kinase. It means the interaction of ligand-Pim 1 kinase stronger to inhibit the performance of Pim 1 kinase in causing cancer. The steric hindrance indicated by the steric interaction between ligand with amino acids of Pim 1 kinase as a receptor will affect the compound as ligand to get close and interact with the active side of the receptor. Bulky substituents would react like hield and encourage the ideal interaction between the ligand and the active side of the receptor. This substituent will help the orientation of the ligand correctly for maximum binding of the ligand with the receptor thus increasing activity of the ligand, but otherwise the steric interaction can also give obstruction of space in the process of interactions of ligand with receptors. The hydrogen bonding interaction of the four top ranked compounds to Pim1 kinase as shown in Figure 2 and Table 3.

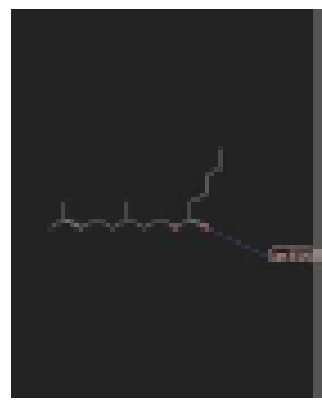

(a)

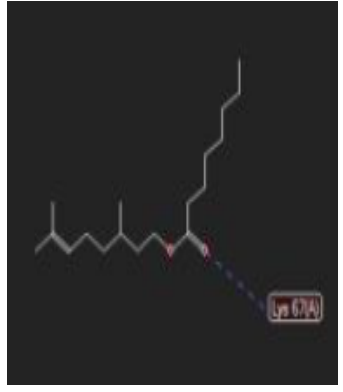

(b)

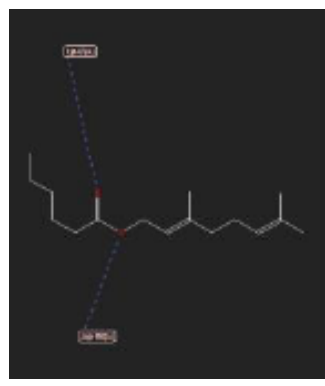

(c)

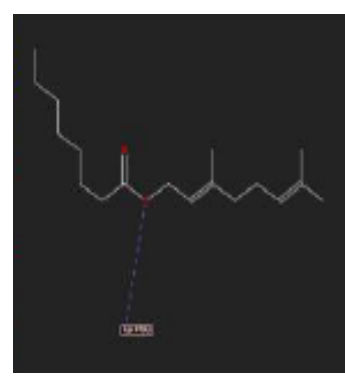

(d)

Figure 2. Hydrogen bonding interaction between Pim1 kinase receptor and citronelly caproate (a), citronelly caprylate (b), geranyl caproate (c), geranyl caprylate (d) 
Table 3. Hydrogen Bond Interaction of CC, CK, GC, and GK with Pim1 Kinase

\begin{tabular}{lll}
\hline \multicolumn{1}{c}{ Compound } & \multicolumn{2}{c}{$\begin{array}{c}\text { Interaction with amino acid residues of the protein target } \\
\text { Pim1 kinase }\end{array}$} \\
\cline { 2 - 3 } & \multicolumn{1}{c}{ Hydrogen interaction } & \multicolumn{1}{c}{ Steric interaction } \\
\hline Citronellyl caproate (CC) & Lys 67 & Val 52, Leu 120, Asn 172, Asp 186 \\
Citronellyl caprylate (CK) & Lys 67 & Val 52, Phe 49, Ile 104 \\
Geranyl Caproate (GC) & Lys 67 and Asp 186 & Asn 172, Ile 104,Leu 174, Val 126 \\
Geranyl Caprylate (GK) & Lys 67 & Lys 67, Asp 186, Phe 187 \\
\hline Noted: RMSD value of all of the compounds of docking results are 0,00
\end{tabular}

Based on the docking results and Lipinski's rule of five, generally the drug compound is as orally active drug if the hydrophobicity value is less than $5(\log \mathrm{P} \leq 5)$, so that citronellyl caproate $(\log \mathrm{P}=4.96)$ and geranyl caproate $(\log \mathrm{P}=4.62)$ are predicted to have potency as a new anticancer candidates for possible therapeutic agents. Generally, natural ester compounds that have been known to have potency as anticancer are a cyclic ester or lactone ester such as $\gamma$-lactone exomethylene that is a aromatic compound that has an oxygen atom in the carbonyl and hydroxyl groups that allow the hydrogen bonds more with the target amino acid of the protein as target receptor thus the interaction more stronger to inhibit the performace of the receptor in causing cancer. Likewise aromatic compounds with amine content which the amine group of the compounds allows the formation of 3 hydrogen bonds or hydrogen interaction thus the bond is stronger in inhibiting the performance of protein as target receptor in causing cancer. Nevertheless, acyclic compounds without amine content such as citronellol and geraniol esters that are acyclic monoterpene esters to be considered as new potential chemopreventive agent for cancer. Besides, both of the compounds are considered to be synthesized and necessary to be cytotoxic activity tested against murine leukemia (P388) cancer cells furthermore. To increase the potency and selectivity of citronellol and geraniol esters as the inhibitors of cancer cell proliferation, the molecular dynamic simulation of citronellol and geraniol ester molecules should be carried out on the active side of the Polo Box Domain (PDB) of Pim 1 kinase as a receptor to study citronellol and geraniol ester interactions to Pim 1 kinase as the target receptor further in the next research.

\section{CONCLUSION}

Based on molecular docking approach, generally citronellol and geraniol ester compounds showed the stronger inhibitory activity of Pim1 kinase and the greater interaction with amino acids residue in the catalytic site of Pim1 kinase compared to citronellol and geraniol. The docking resulted in the four top ranked compounds, namely citronellyl caproate, geranyl caproate, citronellyl caprylate, and geranyl caprylate. Among the four top ranked compounds, citronellyl caproate and geranyl caproate that are acyclic monoterpene ester compounds promising for anti-leukemia cancer agent and considered to be synthesized in the next project.

\section{ACKNOWLEDGEMENTS}

The authors are grateful to the Ministry of Research, Technology, and Higher Education (Kemenristek-DIKTI) of the Republic of Indonesia for funding this research through the Individual Pratama Research Insinas (IRPI) Programs FY 2018-1019. We also thank to Research Center for Chemistry, Indonesian Institute of Sciences (LIPI), and Center of Pharmaceutical and Medical Technologies, Laptiab BPPT for support this research.

\section{REFERENCES}

Arsianti A, Fadilah, Kakiuchi K. 2014. Design and molecular docking study of antimycin $\mathrm{A}_{3}$ analogues as inhibitors of anti-apoptotic BCL-2 of breast cancer. Open J. of Med. Chem. 4: 79-86.

Bayala B, Bassole I, Simpore J. 2014. Anticancer activity of essential oils and their chemical components-a review. Am.J.Cancer Res. 4(6): 591-607. 
Bernard S, Christopher P. 2014. WHO: World Cancer Report. IARC Nonserial Publication. 630. WHO Press.

Biblap B, Jhinuk C. 2013. Identification of proapoptopic, anti-inflammatory, antiproliferative, invasive, and anti-angiogenic targets of essential oils in cardamom by dual reverse virtual screening and binding pose analysis. Asian Pacific Jounal of Cancer Prevention. 14: 3735-3742.

Can BKH, Buchbauer G. 2010. Handbook of Essensial Oil. 56. Printed in the United States of America on acid-free paper.

Cavar S, Maksimovic M. 2012. Antioxidant activity of essensial oil from Palmarosa (Cymbapogon martini). Food Control. 23: 263-267.

Chen W, Viljoen A. 2010. Geraniol-a review of commercial important fragance material. South African J of Botany. 76(4): 643-651.

Christodoulu M, Kontos C, Halabalaki M. 2013. Nature promises new anticancer agents : interplay with the apoptosis-related BCL2 gene family. Anticancer Agent Med.Chem. 13: 1-25.

Cragg GM, Newman DJ. 2013. Natural products as sources of new drug over the last 25 years. J. Nat. Prod. 70: 461-77.

Dykes DJ, Waud WR. 2008. Tumor Models in Cancer Research. 23-40, Humana Press, Totowa, NJ.

Fauser J. 2014. Fatty acids: novel bioactive anticancer therapeutics. Anticancer Agent Med.Chem. . 14: 49-65.

Ganjewala D. 2009. Cymbopogon essential oils: chemical compositions and bioactivities. $J$. Of Essential Oil Therapeutics. 3: 56-65.

Garcia PD, Langowski JL, Wang Y. 2014. Pan-PIM kinase inhibition provides a novel therapy for treating hematologic cancers. Clinical Cancer Research. 30(7): 1834-1845.

Gisele AN, Matthew TB, Wooseok H. 2016. Design, synthesis and structure activity relationship of potent pan-PIM kinase inhibitors derived from the pyridyl carboxamide scaffold. Biorg. Med. Chem. Lett. 26: 2328-2332.
Grassow M, Aparicio C, Carnero A. 2014. The Pim family of Serine/Threonine Kinases in cancer, Med. Research Reviews. 34(1): 136-159.

Hannahan D, Weinberg R. 2010. Lipophilicity in drug discovery. Expert Opin. Drug Disc. 5: $235-248$

Khan AQ, Khan R, Qamar W. 2013. Geraniol attenuate12-O-tetradecanoylphorbol-13acetate (TPA) induced oxidative stress and inflammation in mouse skin: possible role of p38 MAP kinase and NF-xB. Experimental and MolecularPathology. 94(3): 419-429.

Kumar A, Malik F, Bhushan S. 2008. An essential oil and the mayor constituent isointermediol induce apoptosis by increaced expression of mitochondrial cytochrome $\mathrm{c}$ and epical death receptors in human leukaemia HL60 cells. Chem.Biol.Interact. 171: 332-347.

Kusumaningrum S, Budianto E, Kosela S, Sumaryono W, Juniarti F. 2014. The molecular docking of 1,4-naphthoquinone derivatives as inhibitors of Polo-like kinase 1 using Molegro Virtual Docker. J.Appl.Pharmaceutic.Scie. 4(11): 47-53.

Li Q, Cheng T, Wang Y. 2011. Drug discovery today. Pub. Chem. Drug Disc. 15(23): 1052-1057.

Lipinski CA, Lombardo F, Dominy BW. 1997. Experimental and computional approaches to estimate solubility and permeability in drug discovery and development settings. Advanced Drug Delivery Reviews. 23. 325.

Madnooni M, Mansour K, Gholivand M. 2012. Chemical composition, cytotoxicity and antioxidant activities of the essential oil from the leaves of Citrus aurantium L. African J Biotech.11(2): 498-503.

Mandal S, Bandyopadhyay S, Ghosh MK. 2012. Natural products: promising resources for cancer drug discover. Anticancer Agent Med.Chem. 12: 49-75.

Matthew TB, Gisele N, Wooseok H. 2015. Identification of $\mathrm{N}-(4-((1 \mathrm{R}, 3 \mathrm{~S}, 5 \mathrm{~S})-3-$ Amino-5-methylcyclohexyl)pyridin-3-yl)6-(2,6-ifluorophenyl)-5-

fluoropicolinamide (PIM447), a potent and selective proviral insertion site of Moloney Murine Leukemia (PIM) 1, 2, and 3 kinase 
inhibitor in clinical trials for hematological malignancies. J. Med.Chem. 58: 83738378 .

Merkel AL, Meggers E, Ocke M. 2012. Pim1 kinase as a target for cance. Early Online Expert Opin. Investig. Drugs. 1-12.

Narayanan A, Baskaran SA, Amalaradjon M. 2015. Anticarcinogenic properties of medium chain fatty acids on human colonrectal, skin, and breast cancer cells in vitro. Int. J. Mol. Sci. 16: 5014-5027.

Qurishi Y, Hamid A, Majeed R. 2011. Interaction of natural products with cell survival and signaling pathways in the biochemical elucidation of drug targets in cancer. Future Oncol. 7( 8): 1007-1021.

Raut JS, Karuppayil SM. 2014. A Status review on the medicinal properties of essential oil. Ind. Crops. Prod. 62: 250-264.

Ravi S, Sureshkumar C and Dhivya S. 2012. Design, synthesis, and evaluation of Geraniol esters against the inflammation drug target protein TNF- $\alpha$. Int. J. of Curr. Res. 4(9): 40-44.
Sharma P, Mondhe D, Muthiah S. 2009. Anticancer activity of an essential oil from Cymbopogan flexuosus. Chem. Biol. Interact. 179. 2(3): 160-168.

Siswandono. 2015. Rancangan Obat Rasional dan Pemodelan Molekul, Kuliah Umum Kimia Medisinal. 1-62, Labtiap BPPT, Puspiptek Serpong.

Tursynbay Y, Zhang J, Li Z. 2016. Pim-1 kinase as cancer drug target: an update Review. Biomed. Report. 4: 140-146.

Weirauch U, Beckmann N, Thomas M. 2013. Functional Role and Therapeutic Potential of The Pim1 Kinase in Colon Carcinoma. Neoplasia. 15 (7): 783-794.

Widiyarti G, Hanafi M, Kosela S, Budianto E. 2016. Cytotoxic activity of cytronellyl caproate on Murine Leukemia (P388) Cells. Int. J. App. Chem. 12(3): 209-220.

Yanuar A. 2012. Penambatan Molekul, Praktek dan Aplikasi pada Virtual Screening. Fakultas Farmasi Universitas Indonesia. 